\title{
Cardiac Hypertrophy and the Blockade of Angiotensin II Receptors by Losartan in Salt-Loaded Dahl Salt-Sensitive Rats
}

\author{
Koh-ichi Sugimoto, Eiji Gotoh, Izumi Takasaki, Toshiaki Ebina, \\ Tamio Iwamoto, Toshikazu Takizawa, Hiroshi Shionoiri, and Masao Ishii
}

\begin{abstract}
We studied the effects of direct blockade of angiotensin II by a non-peptide angiotensin II receptor $\left(\mathrm{AT}_{1}\right)$ antagonist, losartan, on development of cardiovascular hypertrophy in salt-loaded Dahl salt-sensitive (DS) rats. Six-week-old male DS rats were fed a $4 \% \mathrm{NaCl}$ diet and were simultaneously treated with one of two doses of oral losartan for 7 weeks. Vehicle-treated rats were given tap water alone. Blood pressure and body weight were monitored. The low-dose of losartan $(30 \mathrm{mg} / \mathrm{kg} / \mathrm{day} ; n=12)$ blunted the rise in tail-cuff systolic blood pressure only transiently and did not reduce the left ventricular mass (ratio of left ventricular weight/body weight), when compared to the vehicle control $(n=12)$. The high dose of losartan $(100 \mathrm{mg} / \mathrm{kg} / \mathrm{day} ; n=6)$ blunted the rise in blood pressure; however, left ventricular mass was not significantly lower in rats given the high dose of losartan than in those given vehicle $(n=$ 12). The pressor response to intravenous angiotensin II was greatly suppressed in salt-loaded DS rats treated with $30 \mathrm{mg} / \mathrm{kg} / \mathrm{day}$ of losartan. These results suggest that losartan has minor hypotensive effects without reducing cardiovascular hypertrophy in DS rats fed a $4 \% \mathrm{NaCl}$ diet. We conclude that angiotensin II blockade has only minor effects on hypertension and cardiovascular hypertrophy in saltloaded DS rats, and that the renin-angiotensin system may play no major role in the development of cardiovascular hypertrophy in DS rats on a moderately high-salt diet. (Hypertens Res 1994; 17: 199-203)
\end{abstract}

Key Words: angiotensin II receptor antagonist, hypertension, cardiac hypertrophy, salt loading, Dahl salt-sensitive rat

Inbred lines of Dahl salt-sensitive (DS) rats that become hypertensive when raised on a high-salt diet are available for study (1). Previous reports have shown that the circulating renin-angiotensin system is suppressed in salt-fed DS rats (2-4), and that an angiotensin converting enzyme (ACE) inhibitor has no effect on the rise in blood pressure (1). However, treatment with an angiotensin II (Ang II) receptor antagonist, losartan, can reduce the mortality of DS rats fed an $8 \% \mathrm{NaCl}$ diet, and can blunt the rise in blood pressure only transiently $(5,6)$. Left ventricular hypertrophy in spontaneously hypertensive rats and hypertrophy resulting from a sustained increase in cardiac afterload caused by aortic constriction can be prevented by ACE inhibitors (7-9), which further suggests that Ang II plays a key role in the development or maintenance of cardiac hypertrophy, or both. Cardiac hypertrophy has been demonstrated in salt-loaded DS rats (10); however, whether the renin-angiotensin system participates in cardiac hypertrophy in salt-loaded DS rats or not is unclear.

The present study was designed to investigate the effects of Ang II receptor blockade on the development of cardiac hypertrophy in salt-loaded DS rats. To block Ang II receptors, we used a non-peptide Ang II receptor antagonist, losartan. This compound has been reported to be highly specific for Ang II $\left(\mathrm{AT}_{1}\right)$ receptors, and to block these receptors without agonistic action and without kinin or prostaglandin-induced activities (11-13).

\section{Materials and methods}

Five-week-old male DS rats were obtained from Tsukuba Research Laboratory, Eisai Co., Ltd., Tokyo, Japan. These rats were originally from Brookhaven National Laboratory, Upton, New York, USA. The rats were housed two to three animals per cage and maintained under controlled conditions of light, temperature, and humidity. All animals had free access to tap water and a normal rat chow with $0.3 \% \mathrm{NaCl}$. At the age of 6 weeks, the rats began to receive a rat chow containing $4 \%$ $\mathrm{NaCl}$ (Oriental Kobo Kogyo Co., Ltd., Tokyo, Japan). Then the animals were randomly assigned

From the second Department of Internal Medicine, Yokohama City University School of Medicine, Yokohama, Japan. Address for Reprints: Koh-ichi Sugimoto, M.D., Second Department of Internal Medicine, Yokohama City University School of Medicine, 3-9 Fukuura, Kanazawa-ku, Yokohama 236, Japan.

Received March 3, 1994; accepted in revised form May 10, 1994. 
Table 1. Characteristics of Each Group of DS Rats at the Start of the Study

\begin{tabular}{lcccc}
\hline \multicolumn{1}{c}{ Treatment } & $\begin{array}{c}\text { Dose } \\
(\mathrm{mg} / \mathrm{kg} / \text { day })\end{array}$ & $n$ & $\begin{array}{c}\text { Body weight } \\
(\mathrm{g})\end{array}$ & $\begin{array}{c}\text { SBP } \\
(\mathrm{mmHg})\end{array}$ \\
\hline Vehicle & - & 12 & $201 \pm 5$ & $147 \pm 2$ \\
Losartan & 30 & 12 & $200 \pm 5$ & $148 \pm 1$ \\
\hline Vehicle & - & 12 & $206 \pm 4$ & $149 \pm 2$ \\
Losartan & 100 & 6 & $207 \pm 7$ & $151 \pm 4$ \\
\hline
\end{tabular}

SBP, systolic blood pressure. Values are means \pm SEM.

to an experimental group or a control group. Those in an experimental group were either given 30 $\mathrm{mg} / \mathrm{kg} /$ day $(n=12)$ or $100 \mathrm{mg} / \mathrm{kg} /$ day $(n=6)$ of losartan in the drinking water for 7 weeks. The control groups $(n=12$ each) received tap water alone (Table 1).

Losartan was dissolved in distilled water and added to the drinking water. The concentrations and volumes of the drug solution were adjusted three times a week to ensure that the proper doses were given. SBP and body weight were measured weekly. SBP was recorded in awake rats by an automatic tail-cuff sphygmomanometer (UR-5000, Ueda Co., Ltd., Tokyo, Japan). Hearts were removed after seven weeks of treatment (13 weeks old). Each heart was weighed, and then the atria and the right ventricular free wall were dissected from the interventricular septum. The weight of the interventricular septum plus that of the left ventricle was the left ventricular weight, and the left ventricular weight/body weight ratio was taken as an index of left ventricular mass. Each thoracic descending aorta, from just below the left subclavian artery to above the diaphragm was removed and weighed after the branches were carefully trimmed. The aortic weight was normalized by body weight.

\section{Pressor Response to Exogenous Ang II}

Dose-response curves for change in arterial pressure with Ang II were constructed for the drug. Tenweek-old male DS rats were fed the same rat chow containing $4 \% \mathrm{NaCl}$. Six rats were left untreated as a control group. The losartan-treated group $(n=5)$ received $30 \mathrm{mg} / \mathrm{kg} /$ day of the drug in the drinking water for 2 to 3 weeks. After the treatments, the rats were anesthetized (inactin $100 \mathrm{mg} / \mathrm{kg}$ i.p.), and the right femoral artery and vein were cannulated. The arterial catheter was then attached to a pressure transducer (Gould P23 ID, Gould-Statham, Oxnard, California, USA) for monitoring of arterial blood pressure on a physiologic recorder (Model 7746, NEC San-ei Ltd., Tokyo, Japan). Bolus injections of Ang II were then given through the venous catheter. Successive doses were given after the blood pressure had recovered to the baseline value.

The data were expressed as means \pm SEM, and analyzed with analysis of variance. Differences were considered to be statistically significant when $p$ was less than 0.05 .

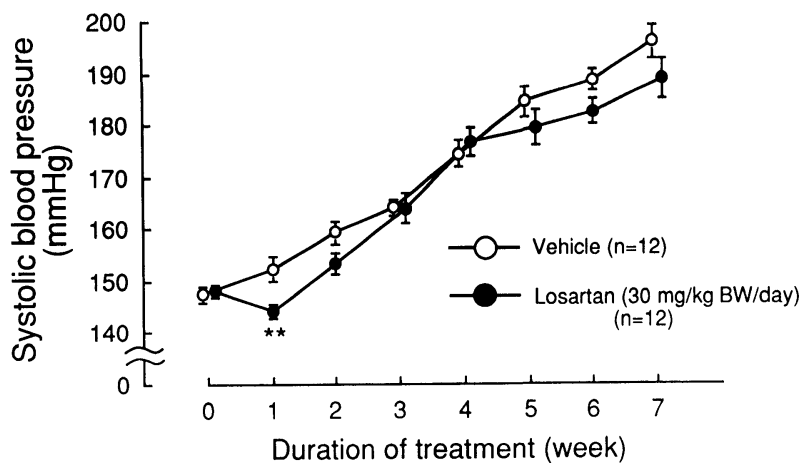

Fig. 1. Line graph shows change in systolic blood pressure during treatment with vehicle and low-dose losartan $(30 \mathrm{mg} / \mathrm{kg} /$ day $) .{ }^{* *} \mathrm{p}<0.01$. Values are means $\pm S E M$.

\section{Results}

\section{Blood Pressure}

In the vehicle- and losartan-treated rats, SBP rose continuously following $4 \%$ salt intake. The low dose of losartan (30 mg/kg/day) blunted the rise in SBP at 1 week; however, SBP averaged $189 \mathrm{mmHg}$ in the losartan-treated rats and $196 \mathrm{mmHg}$ in the vehicle-treated rats (N.S.) at the end of the treatment (Fig. 1).

The high dose of losartan $(100 \mathrm{mg} / \mathrm{kg} /$ day $)$ blunted the rise in blood pressure during the treatment ( $p<0.05$ compared to control). At the end of the treatment,. SBP was lower in the rats given high-dose losartan than in control rats (169 vs. 181 $\mathrm{mmHg} ; p<0.05$ ) (Fig. 2).

\section{Left Ventricular Mass and Aortic Mass}

The effects of drug treatment on left ventricular mass in the salt-loaded DS rats are shown in Table 2 . In the present study, left ventricular mass in DS rats was 2.5 to $2.6 \mathrm{~g} / \mathrm{kg}$ after 7 weeks of $4 \%$ salt loading. Earlier reports showed that left ventricular mass in Dahl salt-resistant rats was not affected by dietary salt intake and was less than $2.2 \mathrm{~g} / \mathrm{kg}(10)$. Thus, we are certain that significant left ventricular hypertrophy was induced by $4 \%$ salt-loading in DS rats. Treatment with 30 or $100 \mathrm{mg} / \mathrm{kg} /$ day of losartan did not affect the left ventricular mass in saltfed DS rats. Losartan did not reduce aortic mass (normalized by body weight or by surface area). 


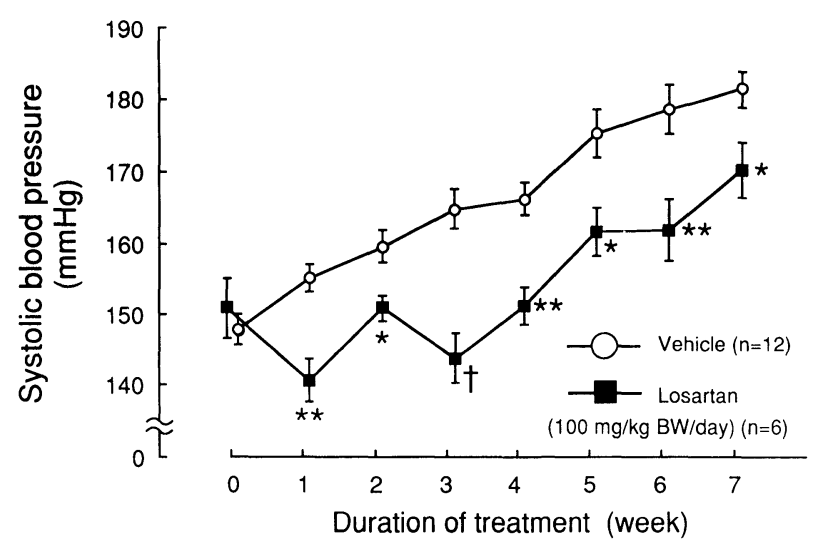

Fig. 2. Line graph shows change in systolic blood pressure during treatment with vehicle and high-dose losartan (100 $\mathrm{mg} / \mathrm{kg} /$ day $) .{ }^{*} \mathrm{p}<0.05,{ }^{* *} \mathrm{p}<0.01$ and ${ }^{\dagger} \mathrm{p}<0.001$. Values are means $\pm S E M$.

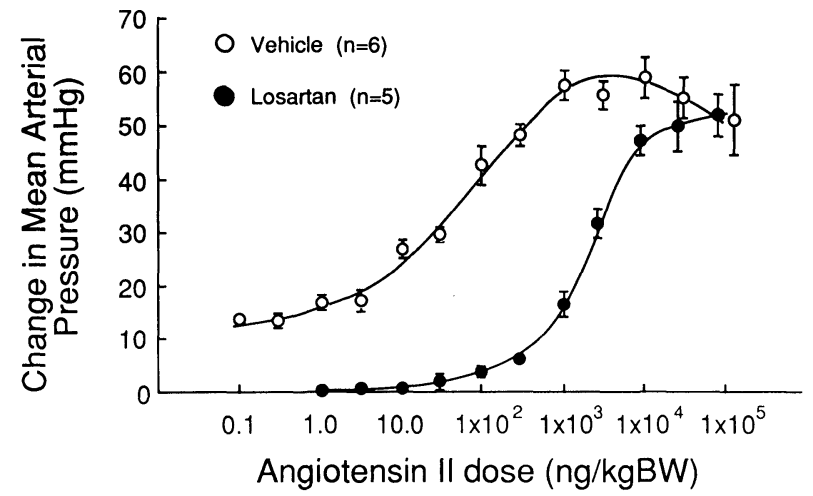

Fig. 3. Line graph shows effects of vehicle and losartan (30 $\mathrm{mg} / \mathrm{kg} /$ day) on changes in mean arterial pressure caused by intravenous angiotensin II. Values are means \pm SEM.

Table 2. Effects of Losartan on Body Weight, Total Heart Weight, Left Ventricular Weight, and Aortic Mass

\begin{tabular}{|c|c|c|c|c|c|c|}
\hline & $n$ & $\begin{array}{c}\text { Body } \\
\text { weight } \\
(\mathrm{g})\end{array}$ & $\begin{array}{c}\text { Heart } \\
\text { weight } \\
(\mathrm{g})\end{array}$ & $\begin{array}{c}\text { Left } \\
\text { ventricular } \\
\text { weight }(\mathrm{g})\end{array}$ & $\begin{array}{c}\text { Left } \\
\text { ventricular } \\
\text { mass }(\mathrm{g} / \mathrm{kg})\end{array}$ & $\begin{array}{l}\text { Aortic } \\
\text { mass } \\
(\mathrm{mg} / \mathrm{g})\end{array}$ \\
\hline \multirow{3}{*}{$\begin{array}{l}\text { Vehicle } \\
\text { Losartan } \\
(30 \mathrm{mg} / \mathrm{kg} / \mathrm{day})\end{array}$} & 12 & $370 \pm 5$ & $1.31 \pm 0.02$ & $0.96 \pm 0.02$ & $2.59 \pm 0.03$ & $0.34 \pm 0.01$ \\
\hline & 12 & $367 \pm 5$ & $1.29 \pm 0.02$ & $0.94 \pm 0.02$ & $2.57 \pm 0.03$ & $0.34 \pm 0.01$ \\
\hline & $n$ & $\begin{array}{c}\text { Body } \\
\text { weight } \\
(\mathrm{g}) \\
\end{array}$ & $\begin{array}{l}\text { Heart } \\
\text { weight } \\
(\mathrm{g})\end{array}$ & $\begin{array}{c}\text { Left } \\
\text { ventricular } \\
\text { weight }(\mathrm{g}) \\
\end{array}$ & $\begin{array}{c}\text { Left } \\
\text { ventricular } \\
\text { mass }(\mathrm{g} / \mathrm{kg}) \\
\end{array}$ & $\begin{array}{c}\text { Aortic } \\
\text { mass } \\
\left(\mathrm{mg} / \mathrm{cm}^{2}\right) \\
\end{array}$ \\
\hline Vehicle & 12 & $363 \pm 4$ & $1.31 \pm 0.02$ & $0.95 \pm 0.02$ & $2.62 \pm 0.03$ & $21.6 \pm 1.0$ \\
\hline $\begin{array}{l}\text { Losartan } \\
(100 \mathrm{mg} / \mathrm{kg} / \text { day })\end{array}$ & 6 & $385 \pm 6$ & $1.40 \pm 0.07$ & $0.98 \pm 0.05$ & $2.54 \pm 0.09$ & $20.4 \pm 0.8$ \\
\hline
\end{tabular}

There were no significant differences (ANOVA). Values are means \pm SEM.

These doses of the antagonist had little effect on the body weight of salt-fed DS rats.

\section{Pressor Response to Exogenous Ang II}

The pressor responses to intravenous Ang II are shown in Fig. 3. Treatment with $30 \mathrm{mg} / \mathrm{kg} /$ day of oral losartan shifted the log-pressor response curve to Ang II rightward in salt-loaded DS rats.

\section{Discussion}

The present data show that treatment with a nonpeptide Ang II receptor antagonist, losartan, had little or no effect on cardiac and aortic hypertrophy in $\mathrm{DS}$ rats fed a $4 \% \mathrm{NaCl}$ diet. Increases in blood pressure were mildly blunted in losartan-treated rats, and the pressor response to exogenous Ang II was markedly suppressed in salt-loaded DS rats treated with $30 \mathrm{mg} / \mathrm{kg} / \mathrm{day}$ of losartan. When 100 $\mathrm{mg} / \mathrm{kg} /$ day of losartan was administered, blood pressure decreased significantly, but left ventricular mass did not decrease. Thus, the small reduction in blood pressure in this study may be not sufficient to prevent the development of left ventricular hypertrophy. An earlier study showed that the decrease in left ventricular mass was less for a given decrease in blood pressure in salt-loaded DS rats (14). This finding suggests that an excessive salt intake impedes the reduction in left ventricular mass, or causes hypertrophy independent of hemodynamic load. Another possibility for a dissociation between reduction in left ventricular mass and fall in blood pressure in salt-loaded DS rats could be a nonlinear relationship between prevention of cardiac hypertrophy and reduction in blood pressure. Despite the obvious Ang II receptor blocking action, this drug had only minor effects on hypertension and cardiovascular hypertrophy in salt-loaded DS rats. Thus, our findings suggest that the reninangiotensin system may play no major role in the development of hypertension and cardiovascular hypertrophy in salt-loaded DS rats.

Ang II stimulates cardiac muscle and vascular smooth muscle cell growth, independent of its effects on vascular resistance and cardiac afterload $(15,16)$. Cardiac and aortic hypertrophy in 
hypertensive animals can be prevented by ACE inhibitors, which also normalize blood pressure (7, $17,18)$. ACE inhibitors can also prevent pressureoverload cardiac hypertrophy in aortic banding rats, without a reduction in blood pressure $(8,9)$. These studies suggest that Ang II plays an important role in the development or maintenance of cardiovascular hypertrophy, or both. In cultured neonatal rat cardiac cells, Ang II increased protein synthesis in myocytes and increased protein and DNA synthesis in cardiac fibroblasts. The $\mathrm{AT}_{1}$ receptor antagonist losartan completely suppressed these effects of Ang II, but the $\mathrm{AT}_{2}$ receptor antagonist PD 123329 did not suppress them significantly (19). These results suggest that AngII-induced cardiac hypertrophy is mediated primarily by the $\mathrm{AT}_{1}$ receptor.

DS rats become hypertensive when raised on a high-salt diet, and have been frequently used as an animal model of salt-induced hypertension (1). The circulating renin-angiotensin system has been reported to be suppressed in salt-loaded DS rats and the hypertension is refractory to ACE inhibitors (1). However, treatment with an Ang II receptor antagonist, losartan, has been shown to markedly reduce the mortality of DS rats fed an $8 \% \mathrm{NaCl}$ diet, and to blunt the rise in blood pressure only transiently (5). In addition, von Lutterotti et al. reported that plasma renin activity (PRA) was initially suppressed in salt-loaded DS rats, and that it then increased after 4 weeks of $8 \%$ salt loading (6). This paradoxical rise in PRA may be due in part to renal vascular damage caused by salt-induced hypertension. These findings suggest that the circulating renin-angiotensin system in salt-loaded DS rats may be activated even when they have been loaded with a high-salt diet, and that the activated reninangiotensin system may participate in the development of end-organ damage in salt-loaded DS rats.

Earlier studies have shown that ACE inhibitors can lower blood pressure in DS rats on a high-salt diet with or without regression of cardiac mass (14, 20 ). Recently, Peeler et al. reported that treatment with enalapril reduced left ventricular mass in DS rats fed an $8 \% \mathrm{NaCl}$ diet without blunting the rise in blood pressure (21). This result suggests that the renin-angiotensin system plays an important role in the development of cardiac hypertrophy even in salt-loaded DS rats, in which cardiac hypertrophy is thought to occur mainly in response to high blood pressure. The source of the discrepancy between these findings and ours is unclear. The Ang II antagonist used in this study is devoid of kinin activity, unlike ACE inhibitors. Therefore, it is possible that an increase in bradykinin may participate in the enalapril-induced reduction of cardiac hypertrophy in salt-loaded DS rats. Besides reducing Ang II, inhibition of ACE also increases bradykinin levels. Thus, it is conceivable that bradykinin also contributes to the prevention of the cardiovascular hypertrophy caused by ACE inhibitors. It has been reported that Hoe 140 , a specific $\mathrm{B}_{2}$-bradykinin receptor antagonist, abolished the antihypertrophic effects of ramipril in left ventricular hypertrophy (22). This observation provides evidence of the in- volvement of bradykinin in the antihypertrophic effects of ACE inhibitors. Another possible explanation is that the circulating or local reninangiotensin system, or both, may remain suppressed in DS rats fed a $4 \% \mathrm{NaCl}$ diet. In DS rats placed on a moderately high-salt diet, cardiovascular hypertrophy could be mainly caused by pressure overload without participation of the reninangiotensin system.

In summary, Ang II blockade by losartan has only minor effects on hypertension and cardiovascular hypertrophy in DS rats fed a 4\% salt diet. These findings suggest that the renin-angiotensin system plays no major role in the development of cardiovascular hypertrophy, at least in DS rats placed on a moderately high-salt diet.

\section{Acknowledgments}

We thank Banyu Pharmaceutical Co., Ltd. (Tokyo, Japan) for supplying losartan. We also thank Kohsai Kido for his technical assistance.

\section{References}

1. Rapp JP: Dahl salt-susceptible and salt-resistant rats. Hypertension 1982; 4: 753-763.

2. Iwai J, Dahl LK, Knudsen KD: Genetic influence on the renin-angiotensin system. Circ Res 1973; 32: 678-684.

3. Rapp JP, Tan SY, Margolius HS: Plasma mineralocorticoids, plasma renin, and urinary kallikrein in salt-sensitive and salt-resistant rats. Endocr Res 1978; 5: $35-41$.

4. Rapp JP, McPartland RP, Sustarsic DL: A qualitative difference in plasma renin activity in Dahl rats susceptible or resistant to salt-induced hypertension. Biochem Gen 1980; 18: 1087-1096.

5. von Lutterotti N, Camergo MJF, Mueller FB, Timmermans PBMWM, Laragh JH: Angiotensin II receptor antagonist markedly reduces mortality in saltloaded Dahl S rats. Am J Hypertens 1991; 4: 346S-349S.

6. von Lutterotti N, Camergo MJF, Campbell WG, et $a l$ : Angiotensin II receptor antagonist delays renal damage and stroke in salt-loaded Dahl salt-sensitive rats. J Hypertens 1992; 10: 949-957.

7. Peffer JM, Reffer MA, Mirsky I, Braunwald E: Regression of left ventricular hypertrophy and prevention of left ventricular dysfunction by captopril in the spontaneously hypertensive rat. Proc Natl Acad Sci USA 1982; 79: 3310-3314.

8. Kromer EP, Riegger GAJ: Effects of long-term angiotensin converting enzyme inhibition on myocardial hypertrophy in experimental aortic stenosis in the rat. Am J Cardiol 1988; 62: 161-163.

9. Baker KE, Chernin MI, Wixson SK, Aceto JF: Renin-angiotensin system involvement in pressureoverload cardiac hypertrophy in rats. Am J Physiol 1990; 259: H324-H332.

10. Pfeffer MA, Pfeffer JM, Mirsky I, Iwai J: Cardiac hypertrophy and performance of Dahl hypertensive rats on graded salt diets. Hypertension 1984; 6: 475-481.

11. Chiu AT, Dunica JV, McCall DE, et al: Nonpeptide angiotensin II receptor antagonists. III. Structurefunction studies. J Pharmacol Exp Ther 1989; 250: 867-874. 
12. Chiu AT, McCall DE, Price WA, et al: Nonpeptide angiotensin II receptor antagonists. VII. Cellular and biochemical pharmacology of DuP 753, an orally active antihypertensive agent. J Pharmacol Exp Ther 1990; 252: 711-718.

13. Wong PC, Price WA, Chiu AT, et al: Nonpeptide angiotensin II reptor antagonists. VIII. Characterization of functional antagonism displayed by DuP 753 , an orally active antihypertensive agent. $J$ Pharmacol Exp Ther 1990; 252: 719-725.

14. Fernandez D, Bolli P, Snedden W, Vasdev S, Fernandez PG: Modulation of left ventricular hypertrophy by dietary salt and inhibition of angiotensin converting enzymes. J Hypertens 1988; 6 (Suppl 4): S145-S147.

15. Aceto JF, Baker KM: [Sar $\left.{ }^{1}\right]$ angiotensin II receptormediated stimulation of protein synthesis in chick heart cells. Am J Physiol 1990; 258: H806-H813.

16. Grinstead WC, Young JB: The myocardial reninangiotensin system: existence, importance, and clinical implications. Am Heart J 1992; 123: 1039-1045.

17. Freslon JL, Giudicelli JF: Compared myocardial and vascular effects of captopril and dihydralazine during hypertension development in spontaneously hypertensive rats. Br J Pharmacol 1983; 80: 533-543.

18. Frohlich ED, Horinaka S: Cardiac and aortic effects of angiotensin converting enzyme inhibitors. Hypertension 1991; 18 (suppl II): II-2-II-7.

19. Sadoshima J, Izumo S: Molecular characterization of angiotensin II-induced hypertrophy of cardiac myocytes and hyperplasia of cardiac fibroblasts, clinical role of the $\mathrm{AT}_{1}$ receptor subtype. Circ Res 1993; 73: $413-423$

20. Sharma JN, Fernandez PG, Kim BK, Idikio H, Triggle CR: Cardiac regression and blood pressure control in the Dahl rat treated with either enalapril maleate (MK 421, an angiotensin converting enzyme inhibitor) or hydrochlorothiazide. J Hypertens 1983; 1: 251-256

21. Peeler TC, Baker KM, Esmurdoc CF, Chernin MI: Angiotensin converting enzyme inhibition in Dahl saltsensitive rats. Mol Cell Biochem 1991, 104: 45-50.

22. Linz W, Schölkens BA: A specific B2-bradykinin receptor antagonist HOE 140 abolishes the antihypertrophic effect of ramipril. Br J Pharmacol 1992; 105: 771-772. 